\title{
Impoliteness Addressed to Different Genders and their Responses in The Kitchen Nightmares, a TV Reality Show
}

\author{
A. Dzo'ul Milal ${ }^{1 *}$, Angga Cahya Pramono ${ }^{2}$ \\ English Department, Faculty of Arts and Humanities, UIN Sunan Ampel Surabaya, \\ Indonesia $^{12}$
}

*Corresponding Author

Email: dzoulmilal@uinsby.ac.id

DOI: http://dx.doi.org/10.18326/jopr.v3i2.131-146

Copyright (C) the Author (s)

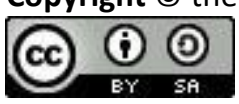

This work is licensed under a Creative Commons Attribution-ShareAlike 4.0 International License.

How to Cite: Milal, A., \& Pramono, A. (2021). Impoliteness Strategies Addressed to Different Genders and their Corresponding Responses. Journal of Pragmatics Research, 3(2).

doi:https://doi.org/10.18326/jopr.v3i2.131-146

\footnotetext{
Submission

Track:

Received:

13-03-2021

Final Revision:

$11-06-2021$

Available online:

01-10-2021

${ }^{*}$ Corresponding

Author:

A. Dzo'ul Milal

dzoulmilal@uinsby.ac.id
}

\begin{abstract}
This paper reveals the impoliteness strategies addressed to different genders and their corresponding responses. The data source is the video transcript of a TV reality show, The Kitchen Nightmares season 6 episode 2 for substantial and technical considerations. As it contains impolite expressions, abundant data can be gained to clarify the focal points. The subjects are the host and male and female participants in that show. This study uses a descriptive qualitative approach. In collecting the data, the researcher identifies the utterances containing impoliteness and their responses in the transcript. Then, they are classified and compared to discover the impoliteness strategies and their responses related to gender differences. It is discovered that, in this show, the types of impoliteness strategies addressed to male addressees are not different from those to female participants. Regarding responses, it is found out that male participants respond to the impoliteness differently from the females. It can be concluded from the show that gender difference is not effective as recipients of impoliteness, but it is operative as producers of the response towards impoliteness.
\end{abstract}

Keywords: entertainment, gender, impoliteness, responses to impoliteness 


\section{INTRODUCTION}

Conflict that is inherent in the plot of human life is thought-provoking and one of its sources is impoliteness. Culpeper (1996) claims that impoliteness may result in social conflict and disharmony. Studying impoliteness can imply that we deal with one of the roots of the problems that underlie the emergence of conflict. As a consequence, understanding impoliteness may be contributive to or can be beneficial for conflict resolution.

Studies have been conducted focusing on impoliteness used in direct or indirect communication or interaction. Shofyah (2015), for example, analyzed the use of impoliteness strategies by the movie characters and the other character's responses toward the impoliteness. The study used a movie entitled Easy. In this study, she found all types of impoliteness performed by the main character. Meanwhile, for the response toward impoliteness, she found the movie characters' responses toward the impoliteness were accepting face attack and offensive countering.

In the field of entertainment shows, Hadi (2020) conducted his research in analyzing impoliteness strategies in UFC Press Conference between Conor McGregor and Khabib Nurmagomedov. He analyzed the impoliteness used by Conor McGregor and the responses uttered by Khabib Nurmagomedov by connecting the use of impoliteness with entertainment factors. He found four types of impoliteness strategies performed by Connor McGregor and all types of responses given by Khabib Nurmagomedov. He claimed that entertainment factors affect the use of impoliteness in the sense that impoliteness strategies were used to make the show more interesting because impoliteness became the source of conflicts. Conflict is one of the factors that produce entertaining effects. The researcher also found that three generic factors existed in McGregor's utterances.

Aprilliyani et al. (2019) analyzed the use of impoliteness in Instagram comments. The data of their study were the comments in the accounts of Habib Rizieq and Felix Siauw. In that study, they analyzed the haters' comments in both accounts. They investigated the impoliteness used by male and female users. The result of this study revealed four kinds of impoliteness strategies used by the users. Sarcasm or mock impoliteness was the highest number that appeared in the comments. The researchers concluded that there was no significant difference between male and female users using impoliteness strategies.

Aydinoglu (2013) investigated the politeness and impoliteness strategies in Geralyn I. Horton's plays. He also compared the use of impoliteness and its response used by male and female characters in the play. His study concluded that male characters uttered impolitely more than the women. It implied that men were more impolite than women. Furthermore, his study showed that women were more exposed to impoliteness than men. Regarding the study of impoliteness, Jumanto (2020) had the opinion that impoliteness takes place in either rude situations or awkward situations. He further explains that impoliteness happens in rude situations 
when close language is used to superiors, whereas awkward situations when distant language is used to close people.

Despite those previous studies, it has not been conclusive as to whether gender is determinant to whom impoliteness strategies are addressed and if their corresponding responses given by male and female are significantly different. Therefore, in this research, the researchers focused to investigate the use of impoliteness toward different genders and whether the responses are constrained by gender differences in the TV reality show, The Kitchen Nightmares.

Studies on pragmatics topics need to consider contexts (Levinson, 1983; Yule, 1996; Birner, 2013). In this study, the researchers tried to explore the use of impoliteness in the context of the TV reality show, The Kitchen Nightmares. In this TV-show, it was told that Gordon Ramsay (henceforth called Ramsay), the host, traveled throughout America to find and repair or give a new breath to restaurants that were almost bankrupt or dying. Ramsay, the presenter or the host, provided input and scathing criticisms to the restaurant owner about changing the restaurant to be better from the concept of the food being served. Scathing criticism and comment in this TV-show were used by the host actually to motivate restaurant owners so that their restaurant could run well again.

Culpeper (1996) defines impoliteness as a means to attack the hearer's face in contrast to politeness strategies proposed by Brown \& Levinson (1987). Every type of politeness has an opposition model called impoliteness strategies. Impoliteness as the communication strategy to attack the hearer's face causes social conflict and disharmony. This is quite contrasting from the politeness strategies, which is designed to promote harmony and avoiding social disruptions (Culpeper et al., 2003). Culpeper (2005) also asserts that to be identified as impolite, the act must be performed intentionally to attack the hearer's face and the hearer must perceive or construct behavior when they receive the attack. Impoliteness is divided into five types: bald on record impoliteness, positive impoliteness, negative impoliteness, sarcasm or mock impoliteness, and withhold politeness. All of these strategies are in opposition with the politeness model of Brown \& Levinson (1987) except sarcasm. Mock impoliteness or sarcasm is a type of impoliteness inspired by Leech's irony model (1983).

As impoliteness is realized in an interpersonal communication, and communication may happen with gender differences, it is important to discuss language and gender. Women and men speak differently (Plug et al., 2021). The study of language and gender was first introduced by Lakoff (1973). Women are more polite than men because of the marginality and powerlessness of women. Lakoff (1973:45) states, "The marginality and powerlessness of women is reflected in both the ways women are expected to speak, and the ways in which women are spoken of." He also states that women are more polite because of their social status in the sense that women have a secondary status in society. Furthermore, the study about language and gender comes to a similar 
conclusion (Holmes, 1995; Mills, 2005). They conclude that impoliteness is more frequently done by men than women.

According to Mills (2003), women are more caring and sympathetic than men. Besides, rather than competitive, women are more cooperative than men. It can also be inferred that women are likely to avoid conflict because of their powerlessness, and the language they use can be a reflection of their powerlessness. On the other hand, Mills (2003) also emphasizes that stereotypically, male masculinity is described with candor and assertiveness. That makes men more likely to be impolite than women. Women who have powerlessness and differences in social status tend to show their awareness of face which is characterized by hesitation or uncertainty. She also mentions that women tend to use negative politeness to show excessive respect when an interlocutor is a man.

The use of impoliteness is influenced by some factors such as the role of women in society and the different approaches of women and men to life. According to Tannen (1990), men reckon their world as a battlefield. It means that men try to achieve and maintain something. However, women assume their life as a negotiation for achieving closeness and support. Women's world demands support from the other. It can be the reason why women are more polite than men.

Considering the relation of politeness or impoliteness and gender differences, it seems that the above discussion only views men and women as the performers of the acts rather than the recipients of the acts. A question arises whether impoliteness strategies are used similarly or differently when the speech is addressed to different genders and whether the corresponding responses are also similar or different based on genders. This research examined impoliteness strategies performed by Ramsay to male and female participants and the responses given by male and female participants toward Ramsay's impoliteness.

Before analyzing the use of impoliteness, its situational context is presented here. Kitchen Nightmares is a TV reality show hosted by one of the popular British celebrity chefs, Gordon Ramsay. His full name is Gordon James Ramsay, born on November $8^{\text {th }}$; 1966, in Johnstone, Scotland. Biography.com editors explain that he left his athletic career and became a famous chef in London, England. He started to enter the television industry with the show Kitchen Nightmares, which was a success in the first season. Ramsay is also successful in his own restaurant business and has received 16 Michelin stars for several of his restaurants. He also managed to expand his business to Dubai. Ramsay started his entertainment career in 1996 with his appearance as a judge on the competitive BBC cooking show Master Chef. Subsequently, he got the opportunity to host two TV shows called Hell's Kitchen and Kitchen Nightmares. His brilliant career brought him the opportunity to be a judge at Masterchef and Master Chef Junior events. Also, Ramsay has written more than 20 books. Its various businesses consolidate into Gordon Ramsay Holdings Limited. (https://www.biography.com/personality/gordon-ramsay) 
In this episode, Ramsay headed to Denver, Colorado, the United States to visit a pizza restaurant. This restaurant is a family business that was on the verge of bankruptcy or failure. Ramsay tried to find something wrong and save this restaurant from bankruptcy. The interest of this episode was that it contained a conflict between Ramsay as the consultant and Pete as the restaurant owner. Ramsay is famous for being a chef who likes to throw criticism and scathing comments if the food does not match his taste. He does not hesitate to say that the food is disgusting. In this episode, Ramsay's impoliteness happened because he tasted really bad food, and because of the restaurant's owner named Pete who was very stubborn. More details about the research subjects are presented in the method.

\section{RESEARCH METHOD}

In this present research, the researchers used a qualitative descriptive approach. It is descriptive in the sense that it merely revealed the existing phenomena, namely the use of impoliteness strategies and their corresponding responses produced by the research subjects and there was no interventional treatment to bring about the data.

The research subjects were Ramsay as the host and the male and female participants of Kitchen Nightmares reality show, season 6 episode 2. Ramsay, the addressor, was the source of the data of impoliteness. In this event, he was a consultant having greater power and higher social status; whereas the addressees, the male participants, Pete, Josh, and Gabe, and the females, Paulette and Celestina, as the clients being powerless and having lower social status were the sources of the data of responses towards the impoliteness. This episode was taken as the data source because it contained sufficiently abundant data of expressions indicating impoliteness strategies and their corresponding responses.

The data were in the form of verbal utterances of Ramsay that contained impoliteness and that of other participants' responses toward the impoliteness. To collect the data, first, the Youtube video (https://www.youtube.com/watch? $\mathrm{v}=1 \mathrm{zxrZdqrpM} 8 \& \mathrm{t}=1268 \mathrm{~s}$ ) was transcribed cautiously and validated by rechecking it several times. The transcript was, then, scrutinized to identify the impoliteness strategies and their responses, and given some codes, i.e. the initials of the impoliteness strategies (e.g. BRI = Bald on Record Impoliteness, PI = Positive Impoliteness, NI = Negative Impoliteness, SMI $=$ Sarcasm or Mock Impoliteness, WP $=$ Withhold Politeness) and their responses (e.g. AFC = Accepting Face Attack, OC = Offensive Countering, DC $=$ Defensive Countering, NR = No Response). For data analysis, the data of impoliteness were classified according to their types, and so were their corresponding responses. Then, the data were compared inter-genders. Finally, the data were concluded and findings were described. 


\section{RESULTS}

The findings are presented about the impoliteness strategies addressed to males and females, and then, about their corresponding responses given by male and female contestants.

\section{Types of Impoliteness toward Males and Females}

This part presents the use of impoliteness addressed to male and female participants uttered by Ramsay in The Kitchen Nightmares. It was revealed that four types of impoliteness strategies were used to males, namely bald on record, positive, negative, and sarcasm or mock. Bald on record impoliteness is the strategy most frequently used, followed by negative impoliteness and positive impoliteness. Sarcasm or mock impoliteness was found only twice. It implied that to males, the impoliteness tended to be direct and clear face attacks. To females, on the other hand, the impoliteness strategies used were bald on record, positive impoliteness, negative impoliteness, sarcasm or mock, and withhold politeness.

\section{Bald on record impoliteness}

According to Culpeper (2005), bald on record impoliteness is an act intended to attack the hearer's face in a brief, direct, and straightforward way. This type of impoliteness strategy is addressed to both males and females.

(1) Ramsay: And do you think your husband is selling the best Pizza in Denver?

Paulette: No, I don't.

Ramsay: You know there's a huge mistake on the awning because I think you just cooked me the worst pizza in Denver.

Pete: I disagree with you.

The sentence in boldface expresses bald on record impoliteness because Ramsay criticized bluntly, openly in front of the public by saying, "you just cooked me the worst pizza." Uttering explicitly that the result of someone's work was the worst was embarrassing. That was a direct and harsh face attack. Ramsay performed bald on record impoliteness by using direct, brief, and concise face attacks because he declared and gave scathing criticism openly that Pete cooked the worst Pizza in Denver.

This type of impoliteness was also addressed to females as found in the following excerpt.

(2) Ramsay: What is that behind your head?

Paulette: That's a hologram.

Ramsay: Freaking me out.

Paulette: You know what, a lot of people are afraid of that. That's a clown.

Ramsay: Oh God. how long's that been about?

Paulette: Oh probably 15 years.

Ramsay: Whose idea was that? That's rude!

Paulette: That's mine. (laugh) 
Ramsay: Oh my god.

In that excerpt, Ramsay's saying "freaking me out" expressed an open disagreement and made the addressee feel ill. Questioning, "Whose idea was that?" intimidated the owner of such an idea of putting a holographic clown in the restaurant. "That's rude!" also implied a direct and succinct face attack on Paulette who had the idea. Those expressions were bald on record impoliteness because they openly attack the face of the addressee.

\section{Positive impoliteness}

Positive impoliteness is a communicative strategy used to damage the hearer's positive face. The positive impoliteness is realized among others by using inappropriate identity markers and showing disinterestedness (Culpeper, 2005). This is addressed to both males and females.

(3) Ramsay: Okay, great, and you have that in 1985 ?

Pete: March 10th of 85, it was Monday we open up.

Ramsay: You know your dates well for an old boy.

Pete: An old boy?

Ramsay: You know old-boy is like a charming old man.

In this excerpt, Ramsay used the phrase an old boy to refer to Pete. That is an inappropriate identity marker because Pete is not a boy. The semantic feature of a boy is minus old. Saying "an old boy," Ramsay insulted Pete because it implied that Pete's biological age is old but his mental age is just like a boy. The phrase old boy is an impolite expression as an attack on Pete's positive face.

This type is also addressed to females. Its realization is showing disinterestedness as found in the following excerpt.

(4) Ramsay: So Celestina! Oh, the dough so thick. Why? I mean it's just like a lot of bread it's like a bargain in that.

Celestina: Umm that's our thin crust.

Ramsay: That's the thin crust?

Celestina: Uhumm.

Ramsay: Stop!

Celestina: (Laugh)

Celestina said she served a thin crust but Ramsay denied that it was thin because the dough was quite thick. When Celestina was about to explain, Ramsay said, "Stop" to her. That order posed a positive face attack because it implied Ramsay was disinterested although Paulette was just about to explain. Ramsay's being disinterested even before Celestina explained was impolite because it attacked Paulette's positive face. 


\section{Negative impoliteness}

Culpeper (1996) mentions negative impoliteness is aimed at damaging the hearer's negative face wants. This impoliteness strategy, among others, is realized in the form of associating the other with negativeness and scorning or ridiculing. This is also used to address males and females.

(5) Ramsay: Pete, you're in denial that's the problem. You cannot just continue going through their system of failure that you're just. You're not getting anywhere, you're just going further backward, and it's not making anybody happy. It's not giving your wife and your family a bit of freedom. It's just feeding your ego.

Pete: I don't know what you say.

Ramsay: You're sinking! You've taken everyone else on the boat with you.

Pete: No, I'm not.

It can be seen from the dialog that Ramsay associated Pete with a sinking boat and that Pete drowned himself and his family. Ramsay means that if Pete continued to feed on his ego, his restaurant would become bankrupt. Ramsay's mentioning a sinking boat and drowning all passengers associated with the bankruptcy of Pete's restaurant and members of his family was a hard talk to Pete and considered impolite because it was associating Pete with negativeness. That is a kind of negative impoliteness.

There is also negative impoliteness addressed to females as shown in the following fragment.

(6) Celestina: You all done with that?

Ramsay: Yeah thank you, darling.

Celestina: No problem.

Ramsay: And this one of the worst urine samples you could ever give.

Celestina: (Laugh) thank you.

The dialogue shows that after tasting the pasta dish at Pete's restaurant, Ramsay found that the pasta had a lot of excess water. Such excess water was compared with the worst urine samples. Comparing the pasta with the worst urine was kind of scorning and ridiculing. Ramsay attacked Celestina's negative face because he despised and ridiculed her.

\section{Sarcasm or mock impoliteness}

According to Culpeper (2005), sarcasm or mock impoliteness is the face attack performed by the speaker indirectly. It was discovered that mock impoliteness or sarcasm was uttered several times by Ramsay to male as well as to female participants. It can be identified by the use of sarcasm or irony by which the speaker utters the opposite meaning of what is intended.

(7) Ramsay: Wow, (laugh) are you nuts? Do you have any idea how many pieces get ordered on a Sunday just in the football season?

Pete: We did open that Sunday in 86.

Ramsay: Congratulations! 86. So how's that affect the business closed two days a week Sunday and Monday. 
Paulette: Nobody knows we're open, I mean we're closed in the afternoon.

Knowing that on the weekends, Pete closes his restaurant on Sundays to watch football, Ramsay uttered his sarcasm. Ramsay thought that Pete's closing the restaurant on Sundays was a bad idea because there was a good sale on weekend. That Ramsay congratulated Pete indicated a mock or sarcasm for Pete because by congratulating, Ramsay meant to despise him. That is a kind of impoliteness because mocking means attacking the face indirectly.

The realization of sarcasm or mock impoliteness to female participants can be seen in the following dialogue.

(8) Celestina: Here we go. The meatball hero

Ramsay: Jesus. The meatball hero. Wow, and how would you, would you eat them?

Celestina: Umm, I guess you approach that very huge fill.

When Celestina served a menu called meatball hero, Ramsay's first impression of the dish was not good because the appearance of the menu is quite large and unattractive. When Ramsay asked Celestina how she would eat such a meatball, he wanted to mock her. Ramsay's real point was that the food was not attractive because of its appearance and its portion. He did not say it directly, but by asking her how she would eat such food. Mocking is an impoliteness strategy by which the addressor attacks the addressee's face indirectly.

\section{Withhold politeness}

Withhold politeness is defined as the face attack that happens when there is no politeness when it is expected by the hearer (Culpeper, 2005). This type of impoliteness was found only addressed to females, and no data were found to be addressed to males.

(9) Ramsay: And this one of the worst urine samples you could ever give. Celestina: (Laugh) thank you.

Ramsay: Holy Crap.

Celestina: Thank you.

Ramsay: Horrible.

The excerpt shows that when Ramsay commented negatively on the pasta by comparing it with the worst urine, Celestina's response was accepting the face attack by saying thanks. That Ramsay did not respond to Celestina's twice thanks is an expression of withholding politeness, in which Celestina had expected her thanks to being responded to, but she accepted a face attack and was trying to take the criticism. Not responding to what is expected is a kind of impoliteness.

\section{Males and Females' Responses toward Impoliteness}

Response toward impoliteness is the reaction that is given by the hearer to impoliteness strategies. According to Culpeper et al. (2003), there are four types of responses to impoliteness 
strategies. Those are accepting face attack, offensive countering, defensive countering, and no response.

In this section, the responses given by male and female participants to Ramsay's impoliteness are presented. It was found that all types of responses, i.e. accepting face attack, offensive countering, defensive countering, and no response existed in participants' utterances. However, the results show a significant difference between genders in the use of responses to impoliteness. It was discovered that the offensive countering type was used most by male participants, especially by Pete. Meanwhile, the accepting face attack response type had the highest frequency used by female participants.

The findings show that there was a difference in responses towards impoliteness given by males and females. Offensive countering was the type of response most often used by male participants, whereas accepting face attacks was most frequently given by females. No data were found about the use of offensive countering made by females. It means that this type was only done by males.

\section{Offensive countering}

According to Culpeper et al. (2003) offensive countering happens when the hearer responds face attack with face attack. This type of response is used by the hearer when the s/he disagrees or is $\mathrm{mad}$ at the impoliteness addressed to him/her. Also, when using this type of response, the speaker tries to save her/his face from losing face or minimizing the possibility of losing face. This type of response was given only by male participants and no data indicated that it was given by females.

(10)Gordon: Pete, you're in denial that's the problem. You can not just continue going through their system of failure that you're just, you're not getting anywhere you're just going further backward, and it's not making anybody happy. It's not giving your wife and your family a bit of freedom. It's just feeding your ego.

Pete: I don't know what you say.

Gordon: You're sinking!

Pete: (Sigh)

In the above dialogue, Ramsay was talking face to face with Pete about Pete's ego that denied the criticism. Ramsay gave Pete a little advice if he wanted his restaurant to survive bankruptcy, Pete should leave away from his ego in running the restaurant. What Ramsay said was clear and straight to the point. However, the response given by Pete showed that he rejected Ramsay's face attack by explicitly ignoring, "I don't know what you say." It indicated that Pete was offensively encountering Ramsay's talk by explicitly rejecting Ramsay's attack. That is a realization of offensive countering to respond to impoliteness. 


\section{Accepting face attack}

Accepting a face attack is a response to impoliteness in which the speaker accepts or agrees with the face attack addressed to him/her. That is due to the relative power the speaker has over the hearer (Culpeper et al., 2003). The researcher found several utterances by male participants that contain this type of response, but for efficiency, one is exemplified.

(11) Ramsay: You mention on the menu that everything's fresh and homemade like mama did.

Pete: So it's first made.

Josh: I don't think the ingredients are required as fresh anymore.

Ramsay attacked the participants' faces by saying that the slogans on the menu books were different from reality. The speech was addressed to Pete, Josh, and Gabe as chefs and co-chefs at the restaurant. A different response was uttered by Pete and Josh in the above dialogue. Pete used the defensive countering response type, while Josh accepted the facial attack by confirming that the ingredients were not fresh as he thought they did not need to be so.

The researchers found several times that female participants used accepting face attacks in response to impoliteness. It is the type of response most often used by female participants.

(12) Ramsay: And this one of the worst urine samples you could ever give.

Celestina: (Laugh) thank you.

Ramsay: Holy Crape.

Celestina: Thank you.

Ramsay: Horrible.

The situation in which the hearer accepts a face-threatening act can also be indicated by an unwillingness to continue talking about a topic. Apart from being silent, to minimize the face attack, the hearer can also show humility. The nature of humility was shown by Celestina to minimize the consequences of the facial attacks that she received. In the above dialogue, Celestina responded to Ramsay's impoliteness by saying thank you. This was not intended to express gratitude, but rather not to prolong the conversation, thus stopping the face attacks.

\section{Defensive countering}

Another type of response toward impoliteness is called defensive countering. Bousfield (2008) states that defensive countering is the response to impoliteness which is performed by the hearer to defend his/her face from face attack. The hearer might try to explain or tell the truth to the speaker. This response uttered without any face attack was done by both males and females.

(13) Ramsay: Why you close on Sunday?

Pete: Sunday?

Ramsay: Yes

Pete: Cause I wanna watch a football.

Ramsay: Wow, (laugh) are you nuts? Do you have any idea how many pieces get ordered on a Sunday just in the football season?

Pete: We did open that Sunday in 86. 
When Pete said that he closed his restaurant on weekends because he was going to watch a soccer match, Ramsay was surprised because he thought that closing the restaurant at the weekend or during football season was a wrong decision. Ramsay's face attack occurred when he asked how much profit he would have made if he opened his restaurant during the football season. Pete was aware of the face threat from Ramsay's words. So, he tried to come up with an explanation in which he hoped that the answer would minimize the face attack. Thus, defensive countering was used by Pete by giving some explanation to clarify the point of the face attacks.

Defensive countering was also done by females to counter the impoliteness of the speaker by giving some reasonable explanation.

(14) Ramsay: So Celestina! Oh, the dough so thick. Why? I mean it's just like a lot of bread it's like a bargain in that.

Celestina: Umm that's our thin crust.

Ramsay: That's the thin crust?

Celestina: Uhumm.

Ramsay: Stop!

Celestina: (Laugh)

Ramsay: Wow, Seriously?

Celestina: A lot of people get upset with me for that, when they ask for the thin crust and I bring them the thin crust. (laugh)

Ramsay commented on the dough he thought was quite thick. Celestina replied that it was the thin crust pliers she had at the restaurant. Celestina tried to explain that the restaurant had a thin crust like the one Ramsay saw. Ramsay used bald on record impoliteness but Celestina's response was explaining to maintain her face. Celestina's response certainly aimed to defend herself from losing face. At the end of the dialogue, Celestina also explained that she always served dough like that to the customers.

\section{No response}

The last type of response toward impoliteness is called no response. No response is defined as the response when the hearer is being silent when the hearer receives impoliteness strategies (Bousfield, 2008; Bousfield \& Miriam, 2008). Culpeper et al. (2003) add when the hearer has no opportunity to respond to impoliteness is one factor that affects the use of this response. This was given by males as well as females.

(15) Ramsay: The pizza is not good.

Pete: I'm still gonna disagree with you I really will I'm sorry but I am.

Ramsay: I need some fresh air.

Pete: Oke, Sir.

Ramsay: Fuck me.

Pete: (No response) 
In that dialogue, Ramsay was frustrated by Pete's stubbornness which made him need fresh air and calm his mind. Ramsay vented his frustration by using positive impoliteness, namely using the swear word, fuck me. Pete gave no response because he knew that Ramsay had to put his mind at ease. By giving no response, Pete did not want to continue his argument with Ramsay.

Giving no response was used by females indicating that she accepted a face attack. It is used by the hearer because s/he does not want to respond or does not have a chance to respond. (Culpeper et al., 2003).

(16) Ramsay: Holy crape.

Paulette: That's ridiculous.

Ramsay: It's like the pizza (indistinct) Denver.

Paulette: Yeah.

Ramsay: Shit.

Paulette: (No response)

Ramsay's utterance above contained a positive impoliteness by using the swear word shit. There are two types of responses that Paulette used in the above dialogue, namely accepting face attack and no response. By saying Yeah, Paulette accepted Ramsay's face attack. At the end of the dialogue, Paulette did not respond to Ramsay's impoliteness of using swear words because she wanted to maintain her face by being silent or giving no response.

\section{DISCUSSION}

This study was conducted to describe the use of impoliteness and its responses taking gender differences into account. The context was a TV reality show, The Kitchen Nightmares season 6 episode 2, where Ramsay, the host, who was a cooking expert and a culinary business consultant, was the performer of the impoliteness acts and male and female participants, the restaurant owner and his assistants, as the consultees, were the recipients of and respondents to the impoliteness acts. Viewing that setting, the social relationship between the two parties, the host and the male and female participants, was that the host had higher status and power, and the situational context was a coaching clinic. As a TV show, furthermore, it must have entertaining purposes.

The findings revealed that impoliteness was performed by the consultant, as the host of the show, to the clients, while the responses were given by the clients, as the participants of the show towards the impoliteness addressed to them. It was discovered that there was no difference between the use of impoliteness addressed to males and that to females. This was complementary to Aydinoglu's study (2013), in which Aydinoglu compared the quantity or frequency of the use of impoliteness addressed to different genders, this present study focused on the types of impoliteness strategies that were performed by the speaker addressed to different genders.

Concerning the use of impoliteness in the conversation between the host and the participants, the researchers concluded that power relations took place in the performance of 
impoliteness to male and female participants in the data. Power can be indicated by domination over others (Fairclough, 1998). Culpeper (1996) also states the difference in power between the speaker and the hearer might cause impoliteness to occur in the interaction. He further asserts that the speaker who has more relative power has more freedom to be impolite. This assumption is evidenced in Ramsay's impoliteness in that he has the freedom to throw reproaches toward the participants because he had access to give criticism as a part of the entertainment. This is in line with Rahmawati et al. (2021) who found that impoliteness existed in teachers' (as power holder) directive acts.

Secondly, it was inferred that entertainment factors were quite likely to affect Ramsay's use of impoliteness. This is consistent with Culpeper's claim that impoliteness can be entertaining (Culpeper, 2005). The result of this study showed that impoliteness strategies were the tool of entertainment in the TV show. This is in line with Hadi's findings (2020) that impoliteness was connected with entertainment as was used by Mc Gregor against Nurmagomedov. It was concluded that the exploration of human weakness was displayed in this TV show. By giving the criticism through impoliteness, the show director was successful in creating conflicts among the characters, thus making the plot more fascinating.

Regarding the types of impoliteness strategies used by the host which were not different when it was addressed to different genders, it could be resolved as follows. Although the data source of this study was a TV reality show, where the real personality of the actors might still give color to the performance including the use of language expressions, as an entertainmentbased TV show it was acceptable that actors are requested to play based on scripts or invented stories. Therefore, to strengthen his character and to make the plot more fascinating because of conflicts enacted by impoliteness, it was reasonable that Ramsay was directed to perform as many impolite acts as possible. That was regardless of the gender differences of the addressees.

Concerning the responses given by male and female participants to respond to impoliteness, it was found there was a significant difference in the use of the responses given by different genders. Male participants often performed offensive countering. According to Tannen (1990), men consider their world as a battlefield. In such a battle, men try to achieve and maintain something. The findings of this study reflect Tannen's assumption about how men approach their life. Tannen's assumption was reflected in Pete's responses toward Ramsay in that Pete tried to contradict and give offensive countering against Ramsay's impoliteness. Meanwhile, female participants were more likely to use the accepting face attack. Such a finding was in line with Mill's assumption that women are more cooperative than competitive and their linguistic behavior is likely to avoid conflict as their reflection of their powerlessness (Mills, 2003). In sum, it can be inferred that gender affects the use of responses toward impoliteness.

The findings implicate that the study that relates language to gender, including the use of impoliteness, needs to be comprehensive in the sense that gender should be taken into 
consideration not only as a determinant factor for language producers but also for language recipients. This is in line with accommodation communication theory (Gallois, Ogay, \& Giles, 2006) which says that language should be adjusted according to the addressees' characteristics. This also agrees with the participant feature as one of the contextual indexes in Pragmatics (Yule, 1996) which encompass not only addressors but also addressees.

\section{CONCLUSION}

In the context of this research, where the data source was The Kitchen Nightmares, a TV reality show, it was discovered that the use of impoliteness to male and female participants was a bit different in the types of impoliteness strategies performed to male addressees, i.e. bald on record, positive, negative, and sarcasm or mock impoliteness, while to female participants, there were five types, namely bald on record, positive, negative, sarcasm or mock impoliteness, and withhold politeness. Regarding responses, it was revealed that the difference was significant in that male participants used all types of responses, i.e. accepting face attack, offensive countering, defensive countering, and no response, while the female participants only used three types of responses, namely accepting face attack, defensive countering, and no response. This difference was underlain by the different nature of the genders, in the sense that a male is more assertive and offensive while a female is submissive and defensive.

Since the data in this study were obtained from a TV reality show, the findings are likely to be specific to such a context. To verify such findings to be generalizable to broader circumstances, furthermore, it is recommended that future research is conducted by taking wide-ranging natural social settings in which impoliteness is performed. As the data in this study were obtained mainly by scrutinizing the video transcript, to interpret the speaker's intention in using impoliteness appropriately, moreover, it is suggested that, in future research, data collection also use multiple techniques, such as interviews of the subjects and questionnaires.

\section{REFERENCES}

Aprilliyani, V, Hamzah, \& Wahyuni D. (2019). Impoliteness strategies used by male and female haters of Habib Rizieq and Felix Siauw found in Instagram comments. Journal of English Language and Literature, 8(1), 158-167.

Aydinoglu, N. (2013). Politeness and impoliteness strategies: An analysis of gender differences in Geralyn I. Horton plays. Procedia-Social and Behavioral Sciences, 83, 473-482.

Birner, B. J. (2013). Introduction to pragmatics. Chichester: Wiley-Blackwell.

Bousfield, D. \& Miriam A. L. (2008). Impoliteness in language: Studies on its interplay with power in theory and practice. Berlin: Mouton De Gruyter.

Bousfield, D. (2008). Impoliteness in interaction. Philadelphia and Amsterdam: John Benjamins. 
Brown, P. \& Levinson. S. (1987). Politeness: Some universals in language usage. Cambridge: Cambridge University Press.

Culpeper, J. (1996). Towards an anatomy of impoliteness. Journal of Pragmatics, 25, 349-367.

Culpeper, J., Bousfield, D., \& Wichmann, A. (2003). Impoliteness revisited: With special reference to dynamic and prosodic aspects. Journal of Pragmatics, 35, 1545-1579.

Culpeper, J. (2005). Impoliteness and entertainment in the television quiz show: The weakest link. Journal of Politeness Research: Language, Behaviour, Culture, 1, 37-38.

Fairclough, N. (1998). Political discourse in the media: An analytical framework. Sociolinguistic, 17, 125-139.

Gallois, C., Ogay, T., \& Giles, H. (2006). Communication accommodation theory: A look back and a look ahead. In W.B. Gudykunst (ed.), Theorizing about Communication and Culture. Thousand Oaks: Sage, 121-148.

Hadi, S. (2020). Impoliteness in UFC press conference. Unpublished Thesis. Surabaya: UIN Sunan Ampel Surabaya.

Holmes, J. (1995). Women, men, and politeness. London: Longman.

Jumanto, J. (2020). Pondering a global BIPA: Politeness and impoliteness in verbal interactions. Journal of Pragmatics Research, 2(2), 97-112.

Lakoff, R. (1973). Language and women's place. Language in Society, 2(1), 145-180.

Leech, G. (1983). Principle of pragmatics. London: Longman.

Levinson, S. (1983). Pragmatics. London: Cambridge University Press.

Mills, S. (2003). Gender and politeness. Cambridge: Cambridge University Press.

Mills, S. (2005). Gender and impoliteness. Journal of Politeness Research: Language, Behaviour, Culture, 1(2), 263-280. DOI: 10.1515/jplr.2005.1.2.263.

Plug, I., Stommel, W., Lucassen, P., Olde Hartman, T., Van Dulmen, S., \& Das, E. (2020). Do women and men use language differently in spoken face-to-face interaction? A scoping review. Review of Communication Research, 9, 43-79. Retrieved from https://www.rcommunicationr.org/index.php/rcr/article/view/77.

Rahmawati, L. E., Hidayat, N., \& Kurniawan, A. (2021). Impoliteness of directive speech acts in online Indonesian language learning. Journal of Pragmatics Research, 3(2), 97-107.

Shofyah, N. W. (2015). The use of impoliteness strategies in "Easy" a movie. Unpublished Thesis. Yogyakarta: UIN Sunan Kalijaga Yogyakarta.

Tannen, D. (1990). You just don't understand. New York: Ballerine Books.

Yule, G. (1996). Pragmatics. Oxford: Oxford University Press. 